\title{
Latiblattella avita sp. nov. (Blattaria: Ectobiidae) from the Eocene Kishenehn Formation, Montana, USA
}

\author{
Dale E. Greenwalt and L’ubomír Vidlička
}

\begin{abstract}
Latiblattella avita Greenwalt and Vidlička, 2015, sp. nov., and the first fossil of the genus, is described. The discovery of a fossil representative of this genus suggests that Latiblattella was more widely distributed in the Eocene. The Eocene American cockroach fauna is mostly comprised of what are today, cosmopolitan genera while the extant genus Latiblattella Hebard, 1917 is restricted in its geographical distribution to Central America, Mexico, Florida and Arizona. The discovery of Latiblattella avita, in combination with the recent description of Cariblattoides labandeirai Vršansky et al., 2012, also documents the presence of rather derived representatives of the family Ectobiidae as early as the Middle Eocene.
\end{abstract}

Dale E. Greenwalt. Department of Paleobiology, NMNH, Smithsonian Institution, Washington, District of Columbia, U.S.A. 20013-7012, GreenwaltD@si.edu.

L'ubomír Vidlička. Institute of Zoology, Slovak Academy of Sciences, Dúbravská cesta 9, 84506 Bratislava, Slovakia, lubomir.vidlicka@savba.sk

and Department of Zoology, Faculty of Natural Sciences, Comenius University, Mlynská dolina, Bratislava, 81104 , Slovakia

Keywords: Fossil insect; Cenozoic cockroaches; Pseudophyllodromiinae; new species

\section{INTRODUCTION}

Cockroaches form one of the taxonomically smaller insect orders with only about 5,000 living species, the majority of which are found in tropical forests (Vidlička, 2001; Vršanský et al., 2002; Roth, 2003; Grimaldi and Engel, 2005; Beccaloni and Eggleton, 2013). This contrasts with the high diversity of ecological and behavioral niches occupied by this clade, as exemplified by the recent discoveries of eusocial, jumping, aquatic, extinct predatory, pollinating, troglobitic and luminescent species (Vishniakova, 1973; Zompro and Fritzsche, 1999; Bohn et al., 2010; Vršanský, 2007; 2010; Vršanský and Chorvat, 2013 - but see Greven and Zwanzig, 2013). Extinct species number over 1,000 but nearly $80 \%$ of these are Paleozoic "roachoids" (Mitchell, 2013). The modern cockroach fauna is thought to have evolved immediately after the Cretaceous-Paleogene boundary (Vršanský et al., 2002, 2011, 2012, 2013) although only 53 fossil species have been described from the Cenozoic era (Mitchell, 2013; Arillo and Ortuño,

http://zoobank.org/11628551-F184-435E-8B57-748EB630B6C7

PE Article Number: 18.1.16A

Copyright: Palaeontological Association April 2015

Submission: 24 September 2014. Acceptance: 5 March 2015

Greenwalt, Dale E. and Vidlička, L'ubomír. 2015. Latiblattella avita sp. nov. (Blattaria: Ectobiidae) from the Eocene Kishenehn Formation, Montana, USA. Palaeontologia Electronica 18.1.16A: 1-9. palaeo-electronica.org/content/2015/1118-new-eocene-cockroach 
TABLE 1. The Cenozoic fossils of Ectobiidae.

\begin{tabular}{|c|c|c|c|c|c|}
\hline Subfamily* & Genus & Species & Epoch & Location & Reference \\
\hline Anaplectinae & Anaplecta & $\mathrm{sp}$. & Miocene & Dominican amber & $\begin{array}{l}\text { Gutiérrez and Pérez- } \\
\text { Gelabert, } 2000\end{array}$ \\
\hline Blattellinae & Ischnoptera & $\mathrm{sp}$. & Miocene & $\begin{array}{l}\text { Chiapas amber } \\
\text { (Mexico) }\end{array}$ & $\begin{array}{l}\text { Solórzano Kraemer, } \\
2007\end{array}$ \\
\hline Blattellinae & ?Symploce & rete & Pleistocene & African copal & Gorochov, 2007 \\
\hline Ectobiinae & Agrabtoblatta & symmetrica & Pleistocene & African copal & Gorochov, 2007 \\
\hline Ectobiinae & Ectobius & arverniensis & Paleocene & Menat (France) & Piton, 1940 \\
\hline Ectobiinae & Ectobius & balticus & Eocene & Baltic amber & $\begin{array}{l}\text { Germar and Berendt, } \\
1856\end{array}$ \\
\hline Ectobiinae & Ectobius & menatensis & Paleocene & Menat (France) & Piton, 1940 \\
\hline Ectobiinae & Ectobius & glabellus & Late Oligocene & Rott (Germany) & Statz, 1939 \\
\hline Ectobiinae & Ectobius & kohlsi & Early Eocene & Green River (USA) & Vršanský et al., 2014 \\
\hline Ectobiinae & Ectobius & spp. (3) & Early Eocene & Green River (USA) & Vršanský et al., 2011 \\
\hline Ectobiinae & Isoplates & longipennis & Middle Eocene & \begin{tabular}{|l} 
Gieseltal \\
(Germany)
\end{tabular} & Haupt, 1956 \\
\hline Ectobiinae & Telmablatta & impar & Middle Eocene & $\begin{array}{l}\text { Gieseltal } \\
\text { (Germany) }\end{array}$ & Haupt, 1956 \\
\hline Nyctoborinae & Nyctibora & elongata & Late Oligocene & Rott (Germany) & Statz, 1939 \\
\hline Pseudophyllodromiinae & Cariblatta & spp. (2) & Miocene & Dominican amber & $\begin{array}{l}\text { Gutiérrez and Pérez- } \\
\text { Gelabert, } 2000\end{array}$ \\
\hline Pseudophyllodromiina & Cariblattoides & labandeirae & Early Eocene & Green River (USA) & Vršanský et al., 2012 \\
\hline Pseudophyllodromiina & Euthlastoblatta & $\mathrm{sp}$. & Miocene & Dominican amber & $\begin{array}{l}\text { Gutiérrez and Pérez- } \\
\text { Gelabert, } 2000\end{array}$ \\
\hline Pseudophyllodromiinae & Latiblattella & Avita sp. nov. & Middle Eocene & \begin{tabular}{|l|} 
Kishenehn \\
Formation (USA)
\end{tabular} & $\begin{array}{l}\text { Vidlička and Greenwalt } \\
\text { (This study) }\end{array}$ \\
\hline Pseudophyllodromiinae & Plectoptera & $\mathrm{sp}$. & Miocene & Dominican amber & $\begin{array}{l}\text { Gutiérrez and Pérez- } \\
\text { Gelabert, } 2000\end{array}$ \\
\hline Pseudophyllodromiinae & Plectoptera & electrina & Miocene & Haitian amber & Gorochov, 2007 \\
\hline Pseudophyllodromiinae & Pseudosymploce & $\mathrm{sp}$. & Miocene & Dominican amber & $\begin{array}{l}\text { Gutiérrez and Pérez- } \\
\text { Gelabert, } 2000\end{array}$ \\
\hline Pseudophyllodromiinae & Supella & miocenica & Miocene & $\begin{array}{l}\text { Chiapas amber } \\
\text { (Mexico) }\end{array}$ & Vršanský et al., 2011 \\
\hline \multicolumn{6}{|c|}{ *Subfamily assignments based on Beccaloni (2014) } \\
\hline
\end{tabular}

2005; Solórzano Kraemer, 2007; Gorochov, 2007). Undescribed material includes that presently studied from the Green River (e.g., the genera Blattella Caudell, 1903, Namablatta Rehn, 1937, Diploptera Saussure, 1864, Sigmella Hebard, 1940 and Symploce Hebard, 1916) in Colorado (Vršanský et al., 2011, 2012).

The most speciose family within Blattaria is Ectobiidae $(=$ Blattellidae $)$ with approximately 2,400 species in about 220 genera (Beccaloni and Eggleton, 2013). Ectobius Stephens, 1835 and Phyllodromica Fieber, 1853, two genera in the sub- family Ectobiinae, provide most of the extant cockroach diversity in the Palaearctic (Bohn et al., 2013). Ectobiidae, which originated from the family Mesoblattindae, first appeared in the Early Cretaceous and became dominant during the Cenozoic (Vršanský, 1997; 1999; 2002; Anisyutkin et al., 2008; Wei and Ren, 2013). Fifteen different genera and 13 described and a number of undescribed species representing all five subfamilies of Ectobiidae have been reported in the Cenozoic record (Table 1). Of these, 10 genera have been reported from the New World with the majority, seven, in 
Miocene amber from either Mexico or Hispaniola. Only Cariblattoides labandeirae Vršanský et al., 2012 and Ectobius kohlsi Vršanský et al., 2014 from the Green River Formation in Colorado, and Latiblattella avita Greenwalt and Vidlicka, 2015 sp. nov. from the Kishenehn Formation in Montana, are from North American Eocene deposits.

Dates of the Coal Creek Member of the Kishenehn Formation of northwestern Montana have been estimated to be $46.2 \pm 0.4 \mathrm{Ma}$ (middle Eocene) by ${ }^{40} \mathrm{Ar} /{ }^{39} \mathrm{Ar}$ analysis and $43.5 \pm 4.9 \mathrm{Ma}$ by fission-track analysis (Constenius, 1996). Deposition of the fossiliferous deposits of the middle sequence of the Coal Creek Member occurred in a shallow near-shore setting that exhibited little or no water flow in a seasonal subtropical/tropical environment (reviewed in Greenwalt et al., 2015, in press). The Kishenehn fossil insect fauna is quite diverse with 15 different orders identified to date although only a single specimen (USNM 595139) out of 6,558 is from the order Blattaria (Greenwalt et al., 2015, in press).

\section{MATERIALS AND METHODS}

Specimen USNM 595139 was collected at the Dakin site on the Middle Fork of the Flathead River near Pinnacle, Montana in 2013 in accordance with USFS Authorization HUN281. The piece of oil shale that contained the fossil also contained a fossil notonectid (Heteroptera) and a leg of a tipulid (Diptera). The specimen was photographed with an Olympus SZX12 microscope equipped with a QColor5 Olympus camera. Image-Pro Plus 7.0 software (Media Cybernetics, Inc., Bethesda, MD) was used to capture and record the images. The specimen was immersed in 95\% ethanol for examination and photography. Measurements were made with the Image-Pro Plus 7.0 software. All measurements are in millimeters $(\mathrm{mm})$. Venational terminology is from Vršanský (1997) as originally developed by Comstock and Needham (1898).

\section{SYSTEMATIC PALEONTOLOGY}

Order BLATTARIA Burmeister, 1829 (= Blattariae Latreille, 1810; = Blattodea Brunner von Wattenwyl, 1882)

Family ECTOBIIDAE Brunner von Wattenwyl, 1865 Genus LATIBLATTELLA Hebard, 1917

Type Species. Latiblattella rehni Hebard, 1917 Diagnosis of the genus (after Hebard, 1917), relevant material only. Size moderately large to medium, form moderately broad to very broad, for the group. Tegmina (in fully developed condition, found in numerous species only in the male) delicate, moderately broad, with costal and sutural margins straight and subparallel in greater part, scapular field very broad; discoidal (radial) sectors numerous (usually, including their branches, eight to ten), moderately oblique. Ventral margins of median and caudal femora supplied with elongate, moderately stout spines. First three tarsal joints supplied distad with small pulvilli, brief ventral surface of fourth joint occupied by a pulvillus. Moderately large arolia present.

\section{Latiblattella avita sp. nov.}

(Figures 1-3)

zoobank.org/7225896D-EC71-4088-8B05-008C85F3A7B6

Etymology. The new species name is derived from the latin avitus meaning ancient or ancestral.

Holotype. USNM 595139; a fragment containing an intact tegmen attached (?) to an intact middle leg. Deposited in the Department of Paleobiology, National Museum of Natural History (NMNH), Smithsonian Institution, Washington, District of Columbia.

Type Horizon. Kishenehn Formation, middle Eocene (Lutetian).

Type Locality. Dakin site, Middle Fork of the Flathead River, near Pinnacle, Montana.

Differential Diagnosis. The significantly less oblique radial sectors of the tegmen of Latiblattella avita sp. nov. distinguish it from species in the closely related genera Neoblattella, Shelford, 1911 and Lupparia Walker, 1868. Species of the genus Balta Tepper, 1893 differ from Latiblattella in having a protruded clavus. In addition, the marginal and scapular fields of the tegmina are narrower in Latiblattella than those in Eoblatta Shelford, 1911 (=Balta Tepper, 1893; synonymized by Roth, 1990). L. avita differs from most living representatives of the genus Latiblattella in having a basally forked, wide and darkly pigmented Sc vein as well as a more pronounced coloration.

Description. Tegmen (forewing) elongated, 15.1 $\mathrm{mm}$ long and $4.4 \mathrm{~mm}$ wide (width measured at the distal terminus of the anal field) with a length/width ratio $=3.40$. $S c$ wide and heavily pigmented, arcuate basally with a slight inflection near the anterior margin of the tegmen (Figure 1). Basal of Sc, the tegmen is mottled with black pigmentation (Figures 2, 3.1). Sc itself is $4.75 \mathrm{~mm}$ long and $0.45 \mathrm{~mm}$ in width at the point where it diverges from $R$, and extends to a point about $66 \%$ of the length of the anal field. Sc has no anterior branches. The humeral field is $4.79 \mathrm{~mm}$ long, arcuate basally and without anterior branches. Sc has a single posterior branch which diverges from $S c$ at a point 


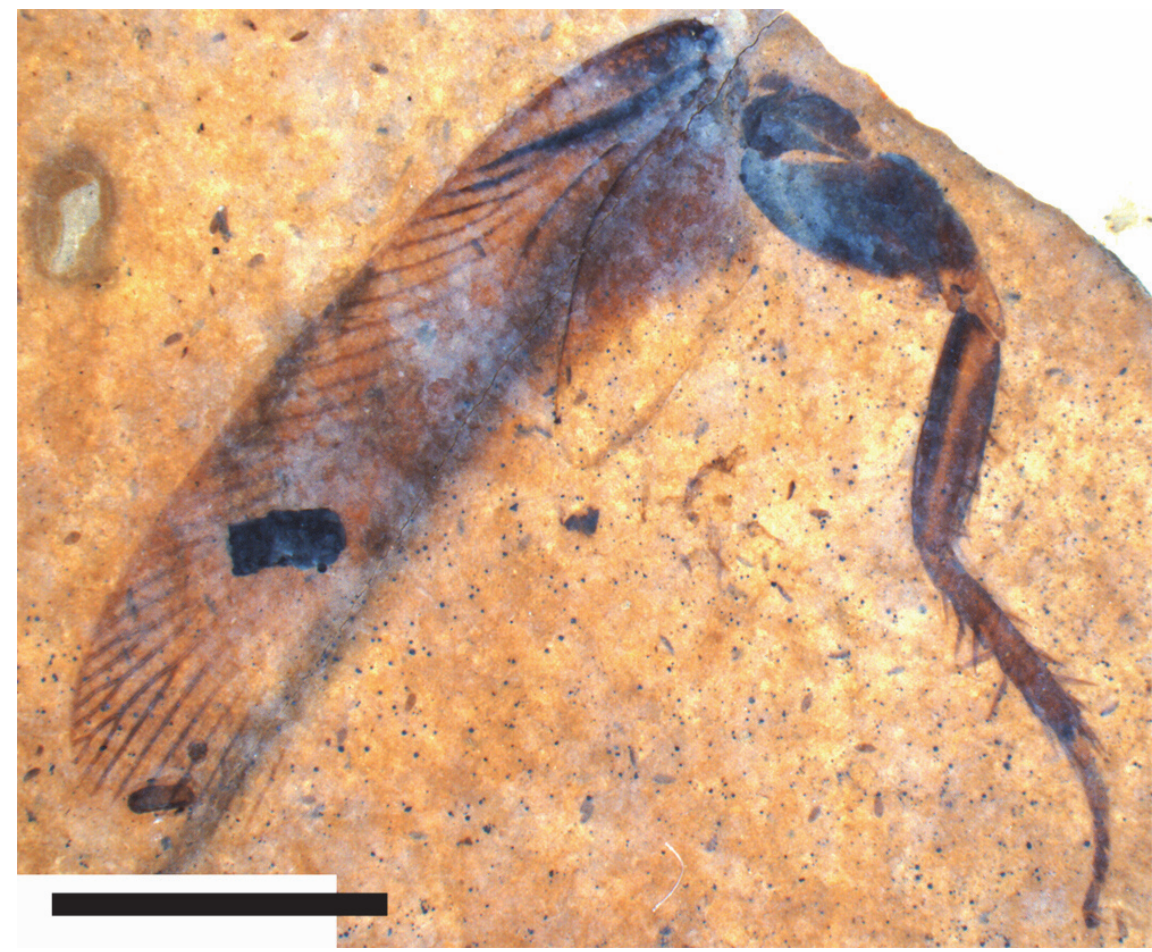

FIGURE 1. Latiblattella avita sp. nov. (USNM 595139). Tegmen attached (?) to an intact middle leg. Scale bar equals $5 \mathrm{~mm}$.

approximately $1 / 2$ the distance from its origin; this vein is heavily pigmented and is $2.18 \mathrm{~mm}$ long and $0.12 \mathrm{~mm}$ wide. Both $\mathrm{Sc}$ and its single branch reach the wing's margin. The basal portion of the radius is distinctly curved and is pigmented to a point 4.5 $\mathrm{mm}$ from the wing's base. There are 10-12 apical branches of the radius - the origins of these branches are not preserved. These branches are oblique, evenly spaced and approximately half of them are branched. The apical radial branches are complexly branched and, with the anterior branches of $M$, parallel to subparallel to the anterior margin of the tegmen. Overall number of $R$ branches meeting margin is 26 . Posterior branches of $\mathrm{M}$ and those of $\mathrm{Cu}$ subparallel to the tegmen's longitudinal margin. The radial field is $8.5 \mathrm{~mm}$ long. The apex of the tegmen is evenly curved. Intercalated veins and crossveins are invisible throughout the membrane. The anal field is $6.58 \mathrm{~mm}$ long and $2.51 \mathrm{~mm}$ wide at its widest point and contains at least 10 near parallel simple longitudinal veins. The plical furrow is subangulate and pigmented basally. The plical notch is distinct although the posterior margin of the tegmen is poorly preserved. The tegmen is brown in coloration, more darkly brown within a wide longitudinal stripe along the central part of the wing with the margins of the wing lighter in color. The anal field is dark brown except for the postero-apical third which is essentially the same color as the shale matrix. Given the poor preservation of the posterior tegminal margin, the distribution of color may have been affected by taphonomic processes. Given the length of the tegmen of this specimen, the insect may have been a male (see Discussion).

In cockroaches, the dorsal aspect of the base of the coxa is very closely apposed to the base of the forewing and, given its size and association with the forewing, the leg of this fossil may be a mesothoracic appendage (Figure 1). It is $13 \mathrm{~mm}$ in total length. The coxa, which is attached to the preserved thoracal-coxal joint, is $4.05 \mathrm{~mm}$ long, 2.14 $\mathrm{mm}$ wide and black/dark brown in color. The basal portion of the coxa and the trochanter are light brown. The trochanter is triangular in shape, 1.13 $\mathrm{mm}$ long, $0.80 \mathrm{~mm}$ wide and overlaps the basal femur by about $0.5 \mathrm{~mm}$. Its shape resembles that of Ectobiinae [vs. species in Blattellinae (Bazyluk, 1977)]. The femur is brown in color, slightly fusiform in shape, $3.76 \mathrm{~mm}$ long and $1.0 \mathrm{~mm}$ wide. Its posterior margin contains seven or eight relatively short spines approximately $0.4 \mathrm{~mm}$ long and 0.04 $\mathrm{mm}$ wide, mostly on the apical half of the femur. The tibia, also brown in color, is $3.3 \mathrm{~mm}$ long and slightly wider apically $(0.49 \mathrm{~mm}$ vs. $0.56 \mathrm{~mm})$. The tibia contains 14 visible spines, evenly distributed 


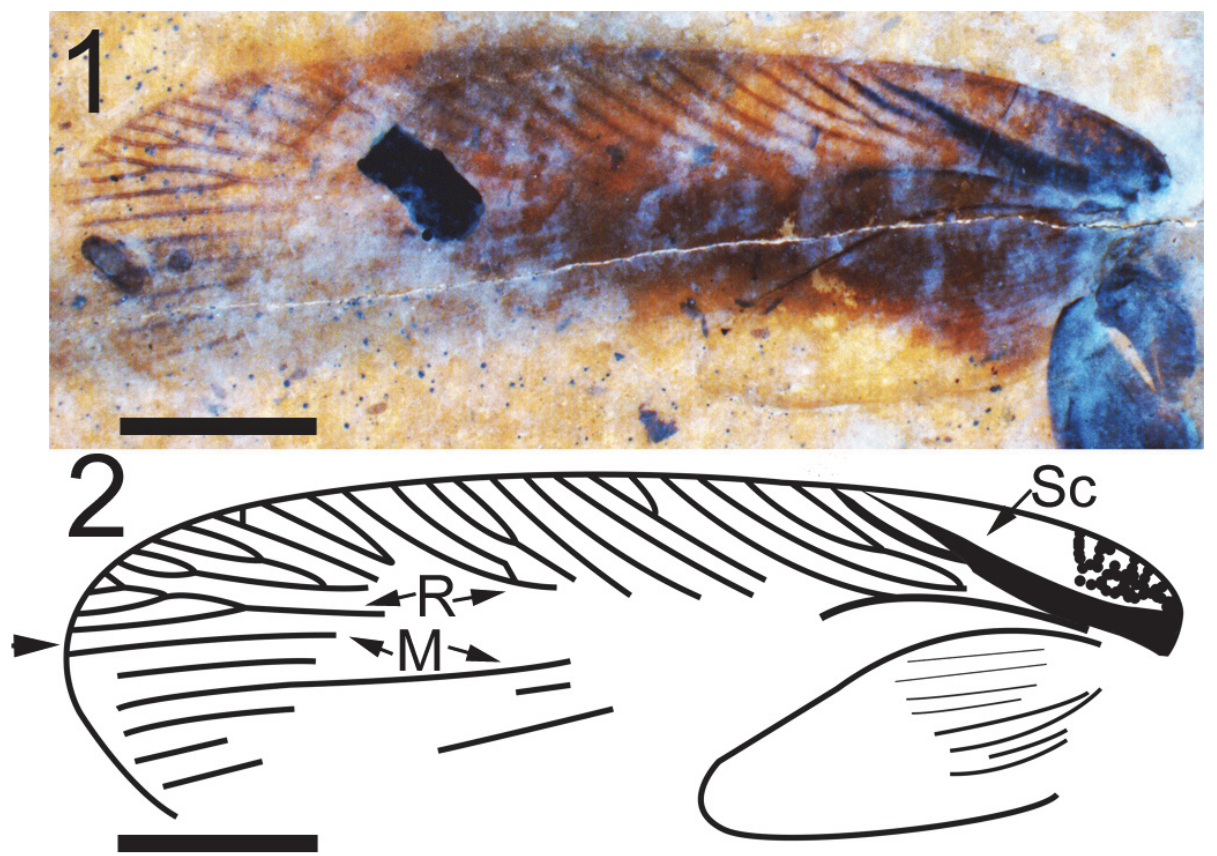

FIGURE 2. Latiblattella avita sp. nov. (USNM 595139). 2.1. A photograph of the tegmen. 2.2. A line drawing of the forewing venation. The arrow denotes the boundary between the radial and medial fields. M, medial veins; $R$, radial veins; Sc, subcostal vein. Scale bar equals $3 \mathrm{~mm}$.

over its length, $0.8 \mathrm{~mm}$ long and $0.08 \mathrm{~mm}$ wide. Four of the tibial spines originate at the terminus of the tibia and lie parallel to the first tarsal segment (Figure 3.2). The dimensions of the five tarsal segments are $1.3 \mathrm{~mm} \times 0.31 \mathrm{~mm}, 0.5 \mathrm{~mm} \times 0.2 \mathrm{~mm}$, $0.35 \mathrm{~mm} \times 0.22 \mathrm{~mm}, 0.2 \mathrm{~mm} \times 0.2 \mathrm{~mm}$ and $0.46 \times$ $0.17 \mathrm{~mm}$ increasing distally to $0.24 \mathrm{~mm}$ wide. T1, T2 and T3 have triangular distal extensions, which may contain remnants of tarsal pads (pulvilli). T4 is bilobed basally, as in Ectobiinae [vs. species in Blattellinae in which the apical and basal margins are parallel (Bazyluk, 1977)]. The single asymmetrical claw that is preserved/visible is approximately $0.36 \mathrm{~mm}$ long. The arolium is about $0.2 \mathrm{~mm}$ in length and black/dark brown.

\section{DISCUSSION}

\section{Assignment of the New Species to the Genus Latiblattella}

The present specimen is categorized within the genus Latiblattella based on the generally unspecialized appearance of the comparatively robust leg, including an asymmetrical claw, nearly identical venation of tegmen with branched Sc, short, pigmented and distinctly curved $R$, more or less straight $M$ and $C u A$, very distinct and arcuate boundary between clavus and rest of the tegmen.
It differs from the related genera Eoblatta and Supella Shelford, 1911 in the decidedly less strongly oblique radial sectors of the tegmen. In addition, the marginal and scapular fields are narrower in Latiblattella than those in Eoblatta. It differs from the related genera Neoblattella and Lupparia in the degree of the obliqueness of the radial sectors of the tegmen; those of Latiblattella are decidedly less oblique. The closely related genus Balta is characterized by a protruded clavus, a morphological character absent in Latiblattella. Nevertheless it is necessary to note that the present specimen has coloration and general appearance somewhat similar to Lupparia adimonialis Walker, 1868 (see plate 1, figure 12 in Shelford, 1908) suggesting a close relationship to the colored representatives of Latiblattella such as the present species. The present specimen is, in contrast to living representatives of the genus, somewhat coloured, but coloration varies greatly within the related cockroach genera. For example, Balta varies from completely colorless to strongly coloured species. The number of veins falls within the variation of the genus (see Rehn, 1951; Brunner von Wattenwyl, 1865). Branching of Sc occurs within the genus, although the basal branching is considered to be a plesiomorphy (i.e., present in ancestral Mesoblattinidae) (Vrsansky et al., 2002). 


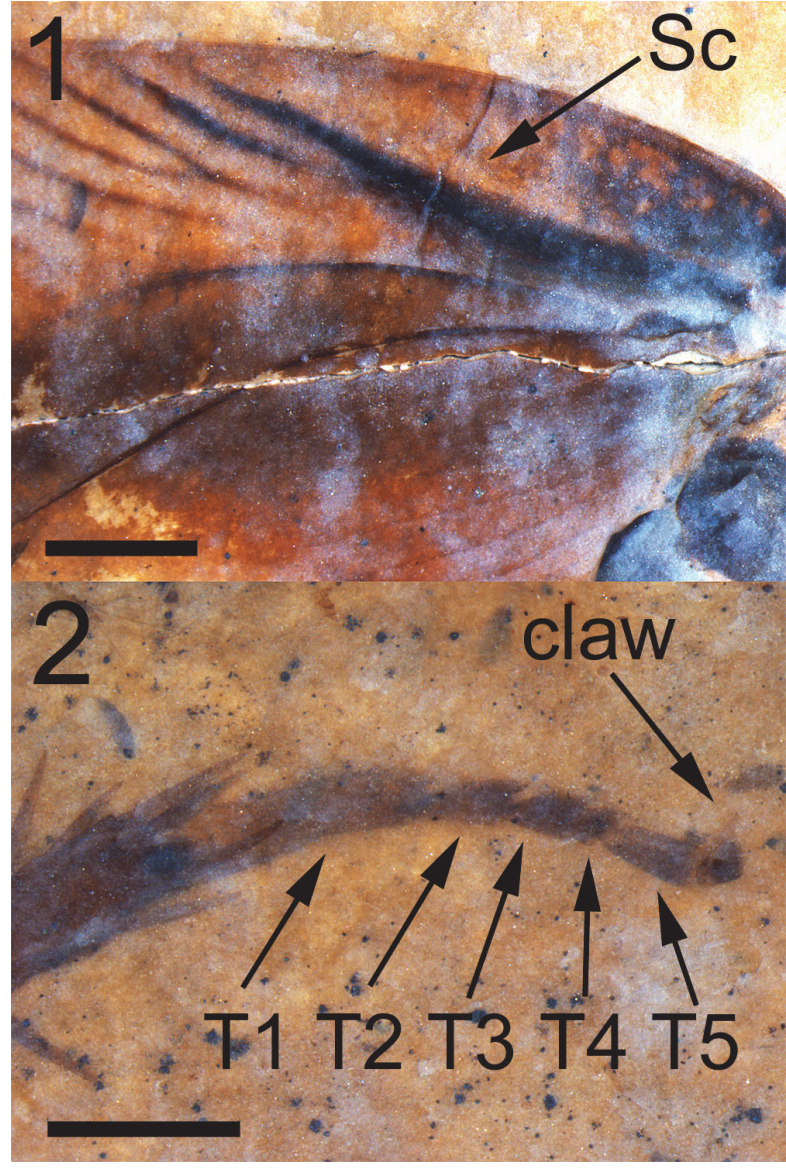

FIGURE 3. Latiblattella avita sp. nov. (USNM 595139). 3.1. The subcostal field of tegmen showing the wide and darkly pigmented Sc vein. 3.2. The five segmented tarsus. The arrows denote tarsal segments $1-5$ and the end of the single visible claw. Scale bars equal 1 $\mathrm{mm}$.

$L$. avita sp.n. has venation almost identical with $L$. rehni. Unfortunately, the data do not reveal enough information for a phylogenetic analysis. While the $S c$ vein is often simple in extant species of Latiblattella, it exhibits a single posterior branch in both $L$. avita and L. vitrea Brunner von Wattenwyl, 1865. The posterior branch originates closer to the forewing margin than the origin of $S c$ in both species. Similarly, in both species, both Sc and the distinctly curved basal portion of the radius are heavily pigmented. Dark pigmentation of the single posterior branch of $S c$ is however unique to $L$. avita.

Extant species of Latiblattella, in addition to exhibiting sexual dimorphism relative to body and wing length such that females often have significantly reduced wings, vary significantly in size (Hebard, 1917, 1921, 1922, 1932). The holotype of Latiblattella vitrea $(\hat{)})$ was reported to have a tegmina length of $10 \mathrm{~mm}$ while that of $L$. mexicana
Saussure, 1864 is $16 \mathrm{~mm}$ (Brunner von Wattenwyl, 1865; Saussure, 1864). L avita sp. $\mathrm{n}$. is $15.1 \mathrm{~mm}$ in length and therefore amongst the largest of the species of this genus. The tegmina length/width ratio of extant species ranges from 3.0 (L. pavida Rehn, 1903) to 4.53 (L. azteca Saussure and Zehntner, 1893) although this latter species is unusual in that most species exhibit a ratio between 3.0 and 3.5 (Rehn, 1903); the tegmina of L. avita sp. $\mathrm{n}$. fits comfortably within this range. The length of the humeral field, defined as the distance, on a line parallel to the wing's anterior margin, from the tegmina's base to the fusion of the primary Sc vein with the wing's margin, relative to that of the anal field, is another potentially valuable morphometric measurement. Unfortunately, most holotypes and paratypes have not been figured in the literature and, as a result, the data is limited. This ratio is equal to 0.92-0.94 (L. rehni), 0.92 (L. lucifrons Hebard, 1917), 0.79 (L. vitrea) and 0.66 (L. avita sp. n.) (Hebard, 1917; Rehn, 1951; Brunner von Wattenwyl, 1865). Given this limited available data and the single fossil specimen, the significance of $L$. avita's smaller ratio is unknown.

\section{Latiblattella avita sp. nov. and the Fossil Record}

Different extant species of Latiblattella have extraordinarily diverse habitats given their small number. L. rehni is found under cracks in the bark of Pinus caribea and within strands of Dendropogon usneoides (Spanish moss), L. chichimeca Saussure and Zehntner, 1893 is found on bromelias, $L$. lucifrons feeds on pollen and detritus on the flowers of Yucca elata and L. zapoteca Saussure, 1862 is found under stones along the margins of rivers (Rehn, 1906; Hebard, 1917; Ball et al., 1942; Blatchley, 1920; Picado, 1913). The conserved fragment of $L$. avita appears to be a remnant that could have been dropped from a predator or washed into the margins of the lake via a small stream and it is impossible to know the niche occupied by the insect. Although pine leaves - yet to be identified - are found in the shales and siltstones of the Kishenehn Formation, none are known from the Dakin site although a single pine seed has been collected there.

Most Cretaceous cockroach clades (e.g., Blattulidae, Caloblattinidae and nearly all of the Mesoblattinidae and Skokidae) are not present in the fossil record of the Cenozoic; only the single extant genus Blattella has a fossil record in the Cretaceous (Vršanský, 2008). On the other hand, nearly all (9/11) cockroach genera from the Green River 
Formation and all genera from Dominican Republic and Mexican amber are extant. The marked differences in the composition of the Cenozoic and Cretaceous entomofauna suggest a very rapid evolution and radiation of the cockroach biota in the Paleocene and early Eocene (Vršanský et al., 2011; 2012; 2013; Gorochov, 2007). Interestingly, Namablatta, Diploptera, Ectobius, Allacta Saussure and Zehntner, 1895, Blattella and Supella are all extant genera that were present in the North and Central American Paleogene that are now, except for recent reintroduction, extinct in those areas (Vršanský et al., 2011). Their absence, in combination with the highly advanced nature and restricted geographical distribution of the Dominican fauna (Central and South America), led Vršanský et al. (2011) to suggest that an environmentally/biologically-mediated extinction event precipitated extinction of Paleogene fauna and set the stage for the evolution of a distinctly American fauna. On the other hand, Cariblattoides labandeira, present in the lacustrine sediments of the early Eocene Green River Formation, is an extant species with a present-day distribution in South America and the Caribbean (Vršanský et al., 2012). Latiblattella avita sp.n. is a species from yet another genus that was able to persist from the middle Eocene to present-day in Central America (An alternative explanation would be the migration of $L$. avita from its Eocene territory to its present day location sometime over the last 46 million years due to the cooling temperatures of the latter half of the Cenozoic.). Extant species of Latiblattella, restricted to Central America, Cuba, Mexico, the Bahamas, Florida and Arizona (Princis, 1969), may be restricted in distribution relative to that of the Eocene. So too, Cariblattoides Rehn and Hebard, 1927, which is presently restricted to Cuba, Puerto Rico and Brazil (Bonfils, 1975). Given their preference for the tropics and the near universal subtropical/ tropical environments of the Eocene (Wolfe, 1995; Zachos et al., 2001), the presence of these genera in Eocene North America is not unexpected. Although recent molecular phylogenetic data has indicated a close relationship between Latiblattella and the oriental genus Balta (Inward et al., 2007), there is no fossil record for the latter genus and a paleobiogeographical link between the two has yet to be established.

\section{ACKNOWLEDGEMENTS}

We thank C. Labandeira and F. Marsh for administrative support and P. Vršanský (GIU SAV, Bratislava) for review of the manuscript. We are also indebted to two anonymous reviewers whose efforts greatly improved the manuscript. This is contribution number 326 of the Evolution of Terrestrial Ecosystems Consortium of the USNM. This research was supported by VEGA 2/0186/13.

\section{REFERENCES}

Anisyutkin, L.N., Rasnitsyn, A.P., and Vršanský, P. 2008. Cockroaches and mantises. Orders Blattodea (= Blattida) and Mantodea (= Mantida), p. 199-209. In Krassilov, V. and Rasnitsyn, A. (eds), Plant-Arthropod interactions over the Early Angiosperm history. Evidence from the Cretaceous of Israel. Pensoft, Sofia-Moscow.

Arillo, A. and Ortuño, V. M. 2005. Catalogue of fossil insect species described from Dominican amber (Miocene). Stuttgarter Beiträge zur Naturkunde B, 352:1-68.

Ball, E. D., Tinkham, E.R., Flock, R., and Vorhies, C.T. 1942. The grasshoppers and other Orthoptera of Arizona. University of Arizona, College of Agriculture, Agricultural Experiment Station, Technical Bulletin, 93:257-373.

Bazyluk, W. 1977. Blattodea and Mantodea. Polish Academy of Science, Institute of Zoology, State Scientific Publishing, Warsaw.

Beccaloni, G. W. 2014. Cockroach Species File Online. Version 5.0/5.0. World Wide Web electronic publication. <http://Cockroach.SpeciesFile.org> [accessed 06 June 2014].

Beccaloni, G.W. and Eggleton, P. 2013. Order Blattodea. Zootaxa, 3703:46-48.

Blatchley, W.S. 1920. Orthoptera of Northeastern America with especial reference to the faunas of Indiana and Florida. The Nature Publishing Company, Indianapolis.

Bohn, H., Picker, M., Klass, K.-D., and Colville, J. 2010. A Jumping Cockroach from South Africa, Saltoblattella montistabularis, gen. nov., spec. nov. (Blattodea: Blattellidae). Arthropod Systematics and Phylogeny, 68:53-69.

Bohn, H., Beccaloni, G., Dorow, W.H.O., and Pfeifer, M.A. 2013. Another species of European Ectobiinae travelling north - the new genus Planuncus and its relatives (Insecta: Blattodea: Ectobiinae). Arthropod Systematics and Phylogeny, 71:139-168.

Bonfils, J. 1975. Blattopera (Orthopteroidea) récoltés en Guyane Francaise par la mission du Muséum national d'Histoire naturelle. Annales de la Societe Entomologique de France (N.S.), 11(1):29-62.

Brunner von Wattenwyl, C. 1865. Nouveau Système des Blattaires. G. Braumüller, Vienne.

Brunner von Wattenwyl, C. 1882. Prodromus der Europäischen Orthopteren. Verlag von Wilhelm Engelmann, Leipzig.

Burmeister, H. 1829. De Insectorum systemate naturali. Dissertatio inauguralis. Halis Saxonum, Typis Grunertorum Patris Filiique. 
Caudell, A. N. 1903. Notes on nomenclature of Blattidae. Proceedings of the Entomological Society of Washington, 5:232-234.

Comstock, J.H. and Needham, J.G. 1898. The Wings of Insects. Chapter III. The Specialization of Wings by Reduction. The American Naturalist, 32:231-257.

Constenius, K. 1996. Late Paleogene extensional collapse of the Cordilleran foreland fold and thrust belt. Geological Society of America Bulletin, 108:20-39.

Fieber, F. X. 1853. Wissenschaftliche Mittheilungen. Synopsis der europäischen Orthoptera. Lotos. Zeitschrift für Naturwissenschaften, 3: 90-104, 115129, 138-154, 168-176, 184-188, 201-207, 232-238, 252-261.

Germar, E.F. and Berendt, G.C. 1856. Die im Bernstein befindlichen Hemipteren und Orthopteren der Vorwelt, p. 1-110. In Berendt G.C. (ed.), Die im Bernstein befindlichen organischen Reste der Vorwelt, vol. 2. Commission der Nicholai Schen Buchhandlung, Berlin, Germany.

Gorochov, A.V. 2007. New and little known Orthopteroid Insects (Polyneoptera) from fossil resins: Communication 2. Paleontological Journal, 41:156-166.

Greenwalt, D.E., Rose, T.R., Siljestrom, S.M., Goreva, Y.S., Constenius, K.N., and Wingerath, J.G. 2015.Taphonomic studies of the fossil insects of the Middle Eocene Kishenehn Formation. Acta Palaeontologica Polonica, in press. dx.doi.org/10.4202/ app.00071.2014

Greven, H. and Zwanzig, N. 2013. Courtship, Mating, and Organisation of the Pronotum in the Glowspot Cockroach Lucihormetica verrucosa (Brunner von Wattenwyl, 1865) (Blattodea: Blaberidae). Entomologie heute, 25:77-97.

Grimaldi, D. and Engel, M.S. 2005. Evolution of the insects. Cambridge University Press, New York.

Gutiérrez, E. and Pérez-Gelabert, D.E., 2000. Annotated checklist of Hispaniolan cockroaches. Transactions of the American Entomological Society, 126:423-445.

Haupt, H. 1956. Beitrag zur Kenntnis der eozänen Arthropodenfauna des Geiseltales. Nova Acta Leopoldina NS, 18:1-90.

Hebard, M. 1916. Studies in the group Ischnopterites (Orthoptera. Blattidae, Pseudomopinae). Transactions of the American Entomological Society, 42:337-383.

Hebard, M. 1917. The Blattidae of North America, north of the Mexican boundary. Memoirs of the American Entomological Society, 2:1-284.

Hebard, M. 1921. Mexican Records of Blattidae (Orthoptera).Transactions of the American Entomological Society, 47(3):199-220.

Hebard, M. 1922. Dermaptera and Orthoptera from the State of Sinaloa, Mexico: Part I. Dermaptera and Non-Saltatorial Orthoptera. Transactions of the American Entomological Society, 48(3):157-196.

Hebard, M. 1932.New Species and Records of Mexican Orthoptera. Transactions of the American Entomological Society, 58(3):201-371.
Hebard, M. 1940. New generic name to replace Sigmoidella Hebard, not of Cushman and Ozana (Orthoptera: Blattidae). Entomological News, 51:236.

Inward, D., Beccaloni, G., and Eggleton, P. 2007. Death of an order: a comprehensive molecular phylogenetic study confirms that termites are eusocial cockroaches. Biology Letters, 3:331-335.

Latreille, P.A. 1810. Considérations générales sur l'ordre naturel des animaux composant les classes des Crustacés, des Arachnides et des Insectes avec un tableau méthodique de leurs genres, disposés en familles. Schoell, Paris.

Mitchell, A.A. 2013. Blattaria occurrence data, accessed 27 July, 2011. EDNA, The Fossil Insect Database. edna.palass-hosting.org/

Picado, C. 1913. Les Broméliacees épiphytes. Considerees comme milieu biologique. Bulletin Scientifique de la France et de la Belgique, 47:215-360.

Piton, L.E. 1940. Paleontologie du gisement eocene de Menat (Puy-de-Dom) (Flore et Faune). Memoires de la Societe d'Histoire Naturelle d'Auvergne, 1:1-303.

Princis, K. 1969. Blattaria: Subordo Epilamproidea: Fam.: Blattellidae, p. 711-1038. In Beier, M. (ed.) Orthopterorum Catalogus, Pars 13. Dr. W. Junk, The Hague.

Rehn, J.A.G. 1903. Studies in American Blattidae. Transactions of the American Entomological Society, 29:259-290

Rehn, J.A.G. 1906. Notes on the Orthoptera of Costa Rica, with descriptions of new species. Proceedings of the Academy of Natural Sciences of Philadelphia, 57:790-843.

Rehn, J.A.G. and Hebard, M. 1927. The Orthoptera of the West Indies. Number 1. Blattidae. Bulletin of the American Museum of Natural History, 54:1-320.

Rehn, J.W.H. 1951. Classification of the Blattaria as indicated by their wings (Orthoptera). Memoirs of the American Entomological Society, 14:1-134.

Rehn, J. A. G. 1937. African and Malagasy Blattidae (Orthoptera): Part III. Proceedings of the Academy of Natural Science of Philadelphia, 89:17-123.

Roth, L.M. 1990. Cockroaches from the Krakatau Islands (Dictyoptera: Blattaria). Mémoirs of the Museum of Victoria, 50(2):357-378.

Roth, L.M. 2003. Systematics and phylogeny of cockroaches (Dictyoptera: Blattaria). Oriental Insects, 37:1-186.

Saussure, H. 1862. Orthoptera nova Americana (Diagnoses praelimiinares). Revue et Magasin de Zoologie Pure et Appliquée, 2(14):163-171.

Saussure, H. de. 1864. Blattarum novarum species aliquot. Revue et Magasin de Zoologie Pure et Appliquée, 2:305-326.

Saussure, H. and Zehntner, L. 1893-1899. Orthoptera. Biologia Centrali Americana: Zoology, Botany and Archeology, 1:13-122. 
Saussure H. and Zehntner L. 1895. Histoire naturelle des Blattides et Mantides, p. 1-244. In: Grandidier A. (ed.), Histoire physique, naturelle et politique de Madagascar. Vol. XXIII: Histoire Naturelle des Orthopteres: Premier Partie: Blattides et Mantides. Paris.

Shelford, R. 1908. Orthoptera Fam. Blattidae Subfam. Phyllodromiinae. Genera Insectorum, 73:1-29.

Shelford, R. W. C. 1911. Preliminary diagnoses of some new genera of Blattidae. Entomologists Monthly Magazine, 22:154-156.

Solórzano Kraemer, M.M. 2007. Systematic, palaeoecology, and palaeobiogeography of the insect fauna from Mexican amber. Palaeontographica (A), 282:1133.

Statz, G. 1939. Geradflügler und Wasserkäfer der Oligozänen Ablagerungen von Rott. Decheniana, 99A:1102.

Stephens, J. F. 1835. [1836-1837]. Illustrations of British Entomology; or, a synopsis of indigenous Insects: containing their generic and specific distinctions; with an account of their metamorphoses, times of appearance, localities, food, and economy, as far as practicable, vol. 6. Mandibulata. Baldwin \& Cradock, London, United Kingdom.

Tepper, J.G.O. 1893. The Blattarae of Australia and Polynesia. Transactions of Royal Society of South Australia, 17:25-130.

Vidlička, L'. 2001. Fauna Slovenska Blattaria - šváby Mantodea - modlivky (Insecta: Orthopteroidea). Veda vydavatel'stvo SAV, Bratislava.

Vishniakova, V.N. 1973. New cockroaches (Insecta: Blattodea) from the Upper Jurassic sediments of Karatau ridge, p. 64-77. In Narchuk, E.P. (ed.), Problems of the Insect Palaeontology. Lectures on the XXIV Annual Readings in Memory of N.A. Kholodkovsky (1-2 April, 1971). Nauka, Leningrad.

Vršanský, P. 1997. Piniblattella gen. nov. - the most ancient genus of the family Blattellidae (Blattodea) from the Lower Cretaceous of Siberia. Entomological Problems, 28:67-79.

Vršanský, P. 1999. Lower Cretaceous Blattaria, p. 167176. In Vršanský, P. (ed.), Proceedings of the First International Palaeoentomological Conference, Moscow 1998. AMBA projects monograph, Bratislava.

Vršanský, P. 2002. Origin and the early evolution of mantises. AMBA Projects, 6:1-16.

Vršanský, P. 2007. Jumping cockroaches (Blattaria, Skokidae fam. n.) from the Late Jurassic of Karatau in Kazakhstan. Biologia, Bratislava, 62:588-592.

Vršanský, P. 2008. Mesozoic relative of the common synanthropic German cockroach (Blattodea). Deutsche Entomologische Zeitschrift, 55 (2):215-221.
Vršanský, P. 2010. Cockroach as the earliest eusocial animal. Acta Geologica Sinica (english edition), 84:793-808.

Vršanský, P. and Chorvát, D. 2013. Luminescent system of Lucihormetica luckae supported by fluorescence lifetime imaging. Naturwissenschaften, 100(11):1099-1101.

Vršanský, P., Vishniakova, V.N., and Rasnitsyn, A.P. 2002. Order Blattida Latreille, 1810, p. 263-270. In Rasnitsyn, A.P. and Quicke, D.L.J. (eds). History of Insects. Kluwer Academic Publishers.

Vršanský, P., Cifuentes-Ruiz, P., Vidlička, L., Čiampor, F. Jr., and Vega, F.J. 2011. Afro-Asian cockroach from Chiapas amber and the lost Tertiary American entomofauna. Geologica Carpathica, 62:463-475.

Vršanský, P., Vidlička, L., Čiampor, F. Jr., and Marsh, F. 2012. Derived, still living cockroach genus Cariblattoides (Blattida: Blattellidae) from the Eocene sediments of Green River in Colorado, USA. Insect Science, 19:143-152.

Vršanský, P., Vidlička, L., Barna, P., Bugdaeva, E., and Markevich, V. 2013. Paleocene origin of the cockroach families Blaberidae and Corydiidae: Evidence from Amur River region of Russia. Zootaxa, 3635:117-126.

Vršanský, P., Oružinský, R., Barna, P., Vidlička, L., and Labandeira, C.C., 2014. Native Ectobius (Blattaria: Ectobiidae) from the early Eocene Green River Formation of Colorado and its reintroduction to North America 49 Million years later. Annals of the Entomological Society of America, 107:28-36.

Walker, F. 1868. Catalogue of the specimens of Blattariae in the collection of the British Museum. British Museum (Natural History), London.

Wei, D. and Ren, D. 2013. Completely preserved cockroaches of the family Mesoblattinidae from the Upper Jurassic-Lower Cretaceous Yixian Formation (Liaoning Province, NE China). Geologica Carpathica, 64:291-304

Wolfe, J.A. 1995. Paleoclimatic estimates from Tertiary leaf assemblages. Annual Review of Earth and Planetary Sciences, 23:119-142.

Zachos, J., Pagani, M., Sloan, L., Thomas, E., and Billups, K. 2001. Trends, rhythms and aberrations in global climate $65 \mathrm{Ma}$ to present. Science, 292:686693.

Zompro, O. and Fritzsche, I. 1999. Lucihormetica fenestrata n.gen., n.sp., the first record of luminescence in an orthopteroid insect (Dictyoptera: Blaberidae: Blaberinae: Brachycolini). Amazoniana, 15:211-219. 